\title{
Investigation of relationship between cone penetration test and unit weight in cohesive soil (Study case: Gunung Anyar District)
}

Dian Purnamawati Solin*, Fithri Estikhamah

UPN Veteran East Java, Civil Engineering Department, Indonesia

\begin{abstract}
Cone Penetration Test or CPT is one of soil investigation which is used to determine the mechanical properties of soil i.e., cone resistance and sleeve friction. Since several decades ago, CPT is often used as a common thread to determine the physical properties of soil such as soil unit weight of soil, soil behaviour type, etc. Thus, empirical approaches have been developed from various countries. However, these empirical approaches are not the same as the condition in Indonesia. Therefore, it is necessary to obtain and develop the suitable correlation for the type of cohesive soil. In this study, primary and secondary data were carried out from Gunung Anyar area. From statical analysis result, the regression shows less than $60 \%$ similarity of the model. In addition, the result of this study found that silt and clay soil types were found to dominate in Gunung Anyar area.
\end{abstract}

Keywords: Cone Penetration, Empirical Approaches, Cohesive Soil

\section{Introduction}

In construction field, physical and mechanical properties of soil play an important role in evaluating the types and bearing capacity of soil. Therefore, several tests as well as Standard Penetration Test (SPT), Cone Penetration Test (CPT) and other tests are applied. Among these tests, CPT has been widely used and popular in geotechnical engineering especially in Indonesia. Most of civil engineering project often used $\mathrm{CPT}$ as a soil investigation to estimate the physical and mechanical properties of soil.

$\mathrm{CPT}$ is a test that aims to measures the cone resistance (qc) and sleeve friction (fs) of soil. These values are well known as mechanical properties of soil and really important in designing civil construction. Many decades ago, there were a lot of studies have been aimed to correlate between the value of cone resistance and physical properties of soil as well as soil classification, unit weight of soil, cohesion, etc $[1,2,3,4]$. Robertson et al developed a chart to estimate the soil behaviour type based on the value between friction ratio (FR) and cone resistance $\left(\mathrm{q}_{\mathrm{c}}\right)$ (see Figure 1.). This chart also can be used to determine the value of $\gamma / \gamma_{w}$ [1].

After Lunne et al also presented a method to determine the unit weight of soil by using the soil behaviour type of Robertson et al as can be seen in table 1 [5].

Down to date, there are still many research that presented empirical approaches the correlation between unit weight of soil and cone resistance. However, these empirical studies were designed with soil in another country, which may have many differences with soil conditions in Indonesia. In reducing the occurrence of planning errors, it is highly needed to have empirical approaches that is accordance with existing soil condition.

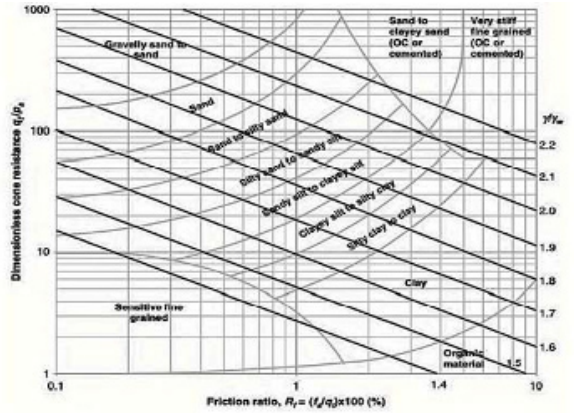

Fig 1. Correlation of FR and Cone Resistance and [1]

Table 1. After Lunne et al, Approximate Soil Unit Weight

\begin{tabular}{|c|l|}
\hline $\begin{array}{c}\text { Approximate unit } \\
\text { weight of soil }(\mathrm{yt}) \\
\left(\mathrm{t} / \mathrm{m}^{3}\right)\end{array}$ & SBT and Soil Description \\
\hline 1.75 & 1. Sensitive fine grained \\
\hline 1.25 & 2. Organic Material \\
\hline 1.75 & 3. Clay \\
\hline 1.8 & 4. Silty clay to clay \\
\hline 1.8 & 5. Clayey silt to silty clay \\
\hline 1.8 & 6. Sandy silt to clayey silt \\
\hline
\end{tabular}

* Corresponding author : diansolin.ts@upnjatim.ac.id 


\begin{tabular}{|c|l|}
\hline 1.85 & 7. Silty sand to sandy silt \\
\hline 1.9 & 8. Sand to silty sand \\
\hline 1.95 & 9. Sand \\
\hline 2.0 & 10. Gravelly sand to sand \\
\hline 2.05 & 11. Very stiff fine grained \\
\hline 1.9 & 12. Sand to clayey sand \\
\hline
\end{tabular}

In this research, the correlation between cone resistance and physical properties of soil in cohesive would be determined by using two sources. Primary data was obtained from direct testing in the field and laboratory and secondary data was obtained from soil investigation in Gunung Anyar area from several private companies. Meanwhile, the purpose of this research was to investigate and determine the relationship between cone resistance and physical properties of soil and can be used to simplify testing of soil in laboratory.

\section{Materials and Method}

\subsection{Study Area}

The study was carried out in Gunung Anyar District as can be seen in the following figure. Gunung Anyar is well known as "pond" area, where almost the entire area of Gunung anyar used to be a fishbond area. So it can be ascetained that the type of soil in this location is cohesive.

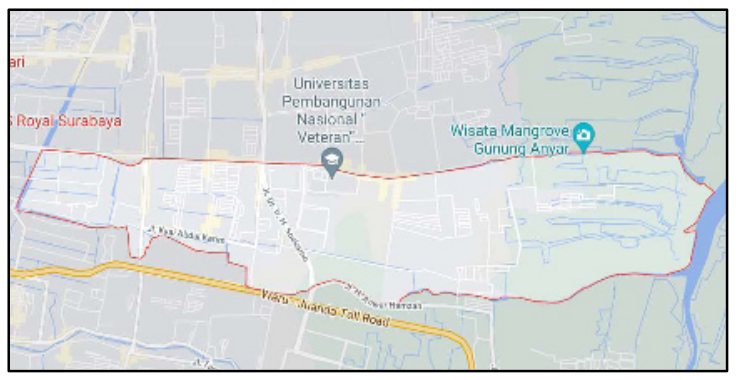

Fig 2. Study Area Gunung Anyar District (Source. Google Maps)

Several data were carried from several locations in Gunung Anyar District including soil investigation from private company laboratory test.

\subsection{Research Methodology}

\subsubsection{Data Collection}

In this research, the data collected comes from two source as well as primary data and secondary data. Primary data is data that comes from the result of sampling and testing samples in laboratory. Meanwhile, secondary data is collected data from site (soil investigation) around the Gunung Anyar district from several companies. The data collected were organized by using Excel software so the depth laboratory tests and in-situ test are same. All the data, both primary and secondary data were recorded in detail and properly to reduce the occurrence of errors during data processing.

\subsubsection{Data Processing}

All the data collected was analysed by using mathematical model. By combining and plotting all the data on a chart it is possible to get a new correlation. The regression obtained from mathematical model would present the relationship between cone resistance and soil unit weight.

\section{Result and Discussion}

Statical analysis was carried out to determine the relation between cone resistance and unit weight of soil. Since the data, both primary and secondary indicates cohesive soil, then some data which is not relevant would be removed. To perform the correlation between cone resistance and unit weight of soil, several mathematical would be applied and the highest regression would be shown. Data analysis was carried out using primary and secondary data that had been collected from Gunung Anyar Area. The primary and secondary data obtained are summarize in the following table.

Table 2. Summary Data

\begin{tabular}{|l|c|c|c|}
\hline Soil Parameters & Min & Max & Average \\
\hline Water Content & $30.93 \%$ & $90.31 \%$ & $59.45 \%$ \\
\hline Void Ratio & 1.02 & 2.6 & 1.58 \\
\hline $\begin{array}{l}\text { Unit weight of } \\
\text { soil }\end{array}$ & $1.43 \mathrm{t} / \mathrm{m}^{2}$ & $\begin{array}{l}1.77 \\
\mathrm{t} / \mathrm{m}^{2}\end{array}$ & $1.558 \mathrm{t} / \mathrm{m}^{2}$ \\
\hline Friction Ration & $1 \%$ & $10 \%$ & $4.02 \%$ \\
\hline Cone Resistance & 2 & 250 & 19.473 \\
\hline
\end{tabular}

\subsection{Soil Behaviour Type}

De Ruiter stated that CPT test can be used to obtain an accurate profile of soil stratification [6]. It is one of the advantages of using CPT test. Classification of soil can be achieved by friction ratio and another derived charts [7]. Friction ratio is well known as ratio between sleeve friction and cone resistance. Friction ratio was measured in percentage. The calculation of friction ration can be expressed as formula bellowed:

$$
F R=\frac{f_{s}}{q_{c}} x 100 \%
$$

There have been many studies on determination of soil classification predicted by friction ratio. Robertson et all presented that the relation between cone resistance $\left(\mathrm{q}_{\mathrm{c}}\right)$ and friction ration (FR) allows to predict soil behaviour type as shown in Figure 1. Lunne et al also suggested a relation between friction ration and soil behaviour type as can be seen in this following table [5].

To shorten the analysis, the friction ration and cone resistance were plotted in one chart to identify the relation between those two values. As can be seen in Figure 3, the friction ratio and cone resistance show a tendency negative with regression $\mathrm{R}^{2}=61.92 \%$. This negative correlation means the higher cone resistance value, the lower friction ratio value. As for the range of friction test in this research was found around $1-10 \%$. 
Compare to table 3 . The type of soil is on silt to peat region.

Table 3 Relation between FR and Soil Classification

\begin{tabular}{|l|l|}
\hline Friction Ratio (FR) & Soil Classification \\
\hline $0.2-0.6$ & Gravel, coarse sand \\
\hline $0.6-1.2$ & Sand \\
\hline $1.2-4.0$ & Silt \\
\hline $3.0-5.0$ & Clay \\
\hline $5.0-7.0$ & Heavy clay \\
\hline $5.0-10.0$ & Peat \\
\hline
\end{tabular}

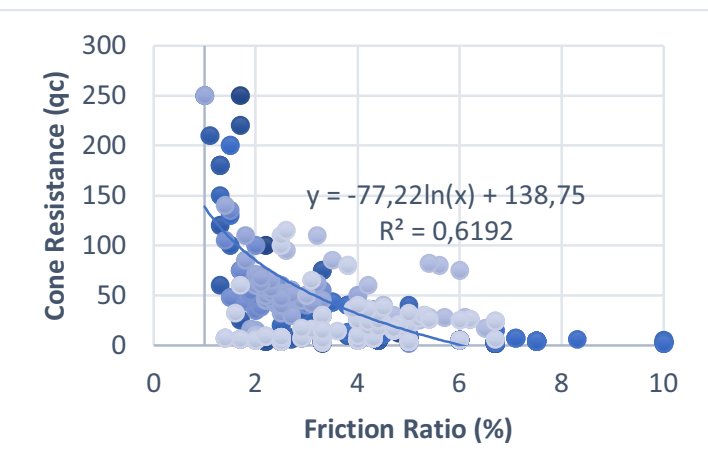

Fig. 3. Friction Ratio and Cone Resistance Relationship Variety

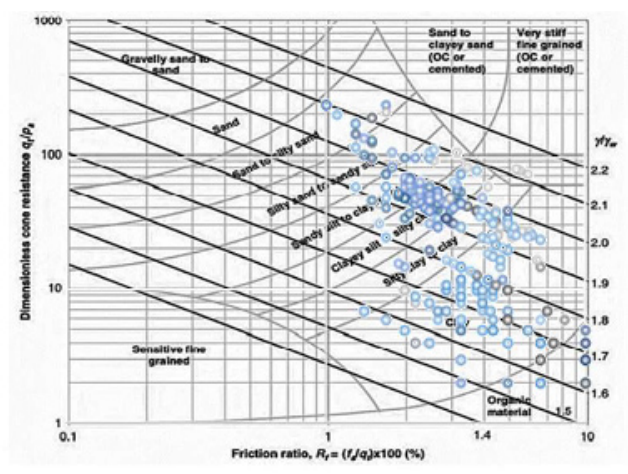

Fig. 4. Plotting FR and qt to predict the SBT result [1]

Figure 4 shows the interpretation of cone resistance and friction ratio. The chart used was made for dimensionless $\left(\mathrm{q}_{t} / \mathrm{p}_{\mathrm{a}}\right)$ where $\mathrm{p}_{\mathrm{a}}$ means atmospheric pressure $=1$ bar. Figure 4 allows a predicted of soil behaviour test. The chart shows that around $80 \%$ of data distribution is in organic material - clayey silt to silty clay region and around $20 \%$ of data distribution is in sandy silt to clayey silt - sand to silty sand region. This result shows the same as the previous results compared to the table 3 .

\subsection{Correlation Between Cone Resistance and Unit Weight of Soil}

Unit weight of soil is one of the physical properties of soil which is often interpreted as the weight of soil per unit area and it is also well known as "soil density". Unit weight of soil is an indicator of the composition of soil particles, air and water content in it. The unit weight of soil can be calculated by the following equation $[9,10]$

$$
\begin{aligned}
\gamma b & =\frac{W}{V} \\
W & =W_{s}+W_{w} \\
V & =V_{s}+V_{w}+V_{a} \\
\mathrm{~V}_{\mathrm{s}} & =\text { Volume of solid particles } \\
\mathrm{V}_{\mathrm{w}} & =\text { Volume of water } \\
\mathrm{V}_{\mathrm{a}} & =\text { Volume of pores } \\
\mathrm{W}_{\mathrm{s}} & =\text { Weight of solid particles } \\
\mathrm{W}_{\mathrm{w}} & =\text { Weight of water }
\end{aligned}
$$

Where: $\quad \mathrm{V}_{\mathrm{s}} \quad=$ Volume of solid particles

By combining the data obtained, between the unit weight of soil and cone resistance on mathematical model. It clearly shows that there is a correlation between those two values that is $\mathrm{y}=1.4348 \mathrm{x}^{0.0339}$ with regression $\mathrm{R}^{2}=0.5804$ (see Figure 5.). This regression result shows that the $\mathrm{R}^{2}<60 \%$ which means the values did not fit good enough to the model. In other words, just around 58\% percent the values fit the model. It can be caused by inconsistencies in taking and sampling the sample of soil around Gunung Anyar area. Therefore, more data is needed to determine the correlation between cone resistance and soil unit weight. Further research still needs to be done to obtain great empirical approaches of this test.

In addition, to see the difference between measured unit weight of soil in Gunung anyar area and Robertson et all charts, a table comparison was conducted (Table 4.). As can be seen in Table 4. There are several similarity and difference between measured unit weight soil classification between Gunung Anyar area and Robertson et al. In Robertson et al chart, we found that $\gamma / \gamma_{w}$ in clay region was plotted from 1.5 to 2.1 . Meanwhile the average measured of soil in Gunung Anyar, the $\gamma / \gamma_{w}=1.552$ for clay. This data was compatible with Robertson et all chart. However, for both silty clay and clayey silt, the average measured were not compatible.

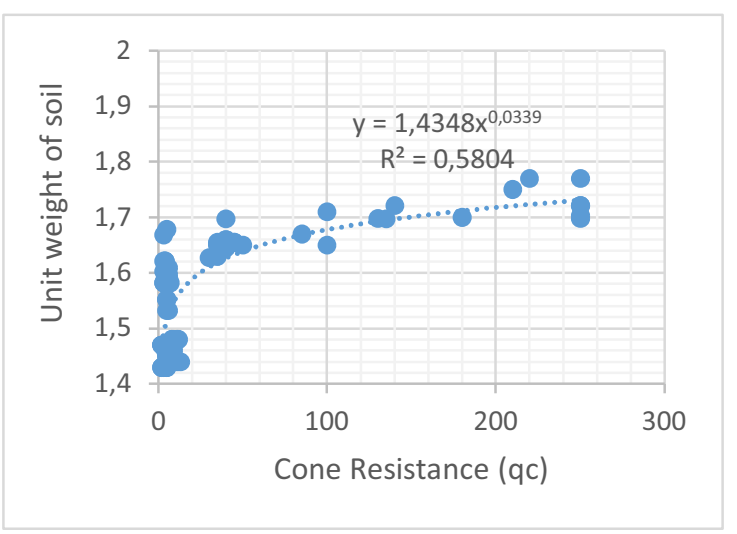

Fig. 4. Correlation Beteen Cone Resistance and Unit Weight of Soil 
Table 4. Comparison Measured Unit Weight and Robertson et al Chart

\begin{tabular}{|c|c|c|c|}
\hline $\begin{array}{c}\text { Measured } \\
\text { Classificati } \\
\text { on of Soil }\end{array}$ & $\begin{array}{c}\text { Average } \\
\text { Measured } \\
\text { unit weight } \\
\text { of soil } \\
\text { Gunung } \\
\text { Anyar }\end{array}$ & $\begin{array}{c}\text { Estimated } \\
\text { Classificati } \\
\text { on of Soil } \\
\text { Robertson } \\
\text { et al }\end{array}$ & $\begin{array}{c}\text { Estimated } \\
\text { unit weight } \\
\text { of soil } \\
\text { Robertson } \\
\text { et al }\end{array}$ \\
\hline Clay & 1.552 & Clay & $1.5-2.1$ \\
\hline Silty clay & 1.6197 & Silty Clay & $1.75-2.2$ \\
\hline Clayey Silt & 1.734 & $\begin{array}{c}\text { Clayey silt } \\
\text { to silty clay }\end{array}$ & $1.85-2.2$ \\
\hline
\end{tabular}

\section{Conclusion}

Based on the result of statical analysis of correlation between cone resistance $\left(\mathrm{q}_{\mathrm{c}}\right)$ and unit weight of soil for Gunung Anyar area, a regression value of $58.04 \%$ was obtained from empirical formula $y=1.4348 \mathrm{x}^{0.0339}$. Since the regression value less than $60 \%$, the empirical approaches cannot be used to represent the relation between those two values. The measured classification of soil from data collected (primary and secondary) also shows several differences compare to estimated unit weight of soil Robertson et al in determining the soil behaviour type. However, the friction ratio value found similarities to previous studies Lunne et al. Lunne et al presented for silt type, FR $=0.6-1.2$ and clay type, FR $=1.2-4.0$, this value is similar with measured friction ratio from data collected.

In obtaining regression $\mathrm{R}^{2} \approx 1$, more data and lab testing are needed to minimize the occurrence of errors in analysing the data, Therefore, further research is needed regarding determination of the correlation between cone resistance and unit weight of soil.

Authors gratefully thanks to the programme UPN Veteran East Java, for supporting this research through Institutional Research grant.

\section{References}

1. P. K Robertson, K. Cabal, Estimating soil unit weight from $C P T$, in $2^{\text {nd }}$ International symposium on cone penetration testing, CPT'10, Hungtington Beach, California.

2. H. K. S. Begemann, The Friction Jacket Cone as An Aid in Determining the Soil Profile, in 6th International Conference on Soil Mechanics and Foundation, pp 17-20, Montreal.

3. B. J. Douglas and R. S. Olsen, Soil Classification Using Electric Cone Penetrometer, in Symposium on Cone Penetration Testing and Experience, Geotechnical Engineering Division, ASCE. St. Louis, Missouri, pp. 209-227, Missouri (1981)

4. A. Anagnostopoulos, G. Koukis, N. Sabatakakis, George Tsiambaos, Emperical Correlation Of Soil Parameters Based On Cone Resitacne Tests For Greek Soil, in Geotechnical and Geoligal engineering 21, pp 377-387, (2003)
5. T. Lunne, P. K Robertson, Cone Penetration Testing in Geotechnical Practice, EF Spon/Blackie Academic, Routledge Publishers, 312 p, London.

6. J. De Ruiter, Electric Penetrometer for Site Investigations, in J. Soil Mechanics \& Foundations Div, ASCE, Vol. 97, No. SM2, pp. 457-472. (1971)

7. P. K Robertson et al, Soil Classification Using the Cone Penetration Test, Can Geotech J 27 (1):151158

8. M.B Jaksa, an improved Technique for evaluating the CPT Friction Ratio, University of Adelaide, (2000).

9. Das, Bradja M, Soil Mechanics, Erlangga, Jakarta (1993)

10. H. Hary Christady, Soil Mechanics 1, Gramedia Pustaka Utama, Jakarta (1992). 